\title{
Development of University Students' Creative Abilities
}

\author{
Gulnara F. Biktagirova ${ }^{1} \&$ Ramilya Sh. Kasimova ${ }^{1}$ \\ ${ }^{1}$ Kazan (Volga region) Federal University, Kazan, Russia \\ Correspondence: Gulnara F. Biktagirova, Kazan (Volga region) Federal University, Kremlyovskaya Street 18, \\ Kazan, 420008, Russia. E-mail: bikgf@mail.ru
}

Received: January 19, 2014

Accepted: February 22, 2015 Online Published: March 25, 2015

doi:10.5539/res.v7n5p101

URL: http://dx.doi.org/10.5539/res.v7n5p101

\begin{abstract}
Development of university students' creative abilities is one of the most important problems of modern education. The article discusses its relevancy and appropriateness, the coverage of this problem in psychological and pedagogical literature and presents the results of the pedagogical experiment. The article describes the basic components of creative abilities development, levels and pedagogical conditions for university students' creative abilities development. The trial infrastructure for the study and the experiment was provided by the Institute of Psychology and Education of Kazan Federal University. The pedagogical experiment proved the correctness of the hypothesis and the relevance of theoretical basis for implementing pedagogical conditions of university students' creative abilities development.
\end{abstract}

Keywords: creativity, creative ability, development of the creative abilities, students' creative abilities

\section{Introduction}

\subsection{Actualizing the Problem}

The society's increasing demand for people able to adapt creatively to any changes, to solve the existing problems in an unconventional and efficient way is due to the accelerating pace of society's development. As a result there is a need to prepare young people for real life in a rapidly changing environment (Valeeva, 2010; Masalimova \& Sabirova, 2014, 2015; Biktagirova \& Valeeva, 2013; Valeeva \& Valeeva, 2013; Shaidullina et al., 2015).

The strategy of modern education is to enable all students to show their talents and creative potential. The more urgent the society's need for the creative initiative of the individual, the greater the importance of the development of theoretical problems of creativity, the study of its nature and forms of expression, its sources, incentives and conditions (Lopatina et al., 2015; Torkunova et al., 2014; Kovaleva et al., 2015; Lisitzina et al., 2014; Sibgatova et al., 2015). These positions correspond to the modern trends of development of humanistic pedagogical school, which is characterized by the orientation of teachers on the personal abilities of students and their continuous "accumulation."

\subsection{Explore Importance of the Problem}

A modern person today is required to be able to act in a situation of choice, set and achieve goals, make his own decisions. On this basis, it is necessary to qualify students with a brand-new mentality whose attitude to their professional duties is creative and pro-active. A creative person is charming and attractive in communication, as he is in constant development and change and open to new life experience. The reality he will have to encounter in life has no unambiguous interpretations in contrast to the reality of educational practice, where the challenges and problems have correct answers beforehand.

Besides, requirements for a future specialist and his functions to perform in professional activity are constantly changing. Today the society requires a professional, able to implement creative activities in innovative fashion and having the desire for self-realization (Sakhieva et al., 2015; Khairullina et al., 2015; Shaidullina et al., 2015; Ganieva et al., 2014; Ivanov et al., 2015; Telegina et al., 2015; Sibgatova et al., 2015). It is impossible without the development of creative abilities of future specialists.

\subsection{Status of a Problem}

In pedagogical and psychological works there is an extensive experience in the study of the problem of creativity and development of creative abilities in the works of Vygotsky (1991), Guilford (1950, 1967), 
Torrance (1964), Greenberg (1974), Bogoyavlensky (2002), Hutorskoy (2000), Shadrikov (2004) and others. The issue of students' creative abilities development was considered by Bono (1993), Matyushkin (2003), Tunik (2006), Shulga (2010). A significant number of works are devoted to studying the issue of development of creative abilities of pupils and students by means of training (Shmakova, 2009; Khusainova, 2010).

The variety of approaches to the problem of cognitive activity, as well as creative activity and creative abilities, on the one hand proves its relevance, but on the other shows its versatility.

However, studies are largely theoretical and methodological in nature, while the practice of modern university requires specific technologies of creative development of students.

\subsection{Hypothesis}

Analysis of theoretical works and practical teaching and research activities in the light of the problem developed showed that today this problem presents an understudied area of scientific knowledge and practice. We hypothesized that the development of creative abilities of students can be effective if the following pedagogical conditions are kept:

- Dialogic teacher-student interaction in the process of creative activity;

- Emotional and intellectual stimulation of students' creative abilities development;

- Inclusion of reflection, or self-analysis mechanism in the development of creative abilities of students (Biktagirova \& Valeeva, 2014);

- Organization of creative activity on the basis of developmental differentiation.

\section{Materials and Methods}

\subsection{Theoretical and Empirical Methods}

To test the hypothesis we used a complex variety of methods, complementing each other:

Theoretical methods: systematic approach, theoretical analysis.

Experimental methods: diagnostic interrogatory (questionnaire, evaluation, testing); observational (direct, indirect, participant observation); practical (the study of pilot curricula focused on the development of creative abilities of students); experimental (ascertaining and formative experiment); statistical and mathematical data processing.

\subsection{The Trial Infrastructure of the Research}

Pedagogical experiment on the development of creative abilities of students was held at the Institute of Psychology and Education of Kazan Federal University from September 2013 to May 2014. The study involved students aged 19 to 21 , totaling 62 people. The research was performed in real life conditions of the educational process.

\subsection{The Stages of the Research}

The research was implemented in three stages:

At the first stage the trial infrastructure of the research at the Institute of Psychology and Education of Kazan Federal University was set; the program was developed and special trainings were implemented in the educational process.

At the second stage, the pedagogical experiment was carried out. There were developed and tested pedagogical conditions of students' creative abilities development. This stage included the following periods:

a) Stating period - the defining of initial values of the studied parameters. At this stage, the following have been identified: the level of students' creative abilities and level of students' self-analyses.

b) Formative period - checking the effectiveness of pedagogical conditions of students' creative abilities development. At this stage the students' creative abilities were developed intentionally.

c) Generalization - systematization and registration of research materials. Control experiment was conducted to verify the changes in the level of creativity and the level of students' self-analyses after formative experiment, there was analyzed the data obtained and summarized the results of hypothesis verification

\subsection{Evaluation Criteria}

To evaluate the effectiveness of students' creative abilities development the following criteria were used:

Cognitive-intellectual criterion contains such psychological components of creativity as fluency, flexibility, originality, curiosity, courage, etc. as well as the skills of a person, which include one's intellectual and logical 
skills and heuristic abilities, which are testified in the ways the person tackles the problems, their novel, unusual and genuine character and in the choice of methods to solve them; the depth and stability of these components, the need for new and creative knowledge.

Individual-reflexive criterion provides the direction to the creative acquirement of knowledge and includes the motives of creative learning and mastering skills of such kind, as well as the ability to defend one's creative position and awareness of worldview features; reflexive self-awareness and reflexive component of "self-image", possession of basic skills of reflexive activity, such as the validity of the research problem, the analysis of one's professional and life experience, the ability to forecast possible difficulties and design tasks aimed at their solving.

Meaningful and aspirational criterion characterizes practical and operational aspects of creative abilities of an individual. These are universal characteristics of any creative activity aimed at self-change and development and suggesting gradual inclusion of students in active learning activities that promote their creative self-development. Meaningful component reflects the sense given in a common goal and in each specific task while aspirational component shows the interaction of subjects of pedagogical process, their cooperation in creating conditions for the development of creative abilities of students.

\subsection{Experimental Procedure and Its Description}

For the organization of the experiment were the levels of development of students' creative abilities, reflecting the logical sequence of this process implementation (spontaneous experiental, reproductive, aspirational and creative) in relation to the studied phenomenon. Each prior level in relation to the next higher level is preparatory, and the newly acquired ability serves as a basis for the development of integrative qualities of the person: motivation, perception, imagination, creative thinking.

Spontaneous experiental (first level) is empirical knowledge about the meaning and essence of creativity and lack of sustained motivation towards self-analysis, self-correction, self-development, and most important, towards the creative activity. The lack of personal experience of creative activity, mainly the use of the experiences of other teachers, described in the literature or heard.

Reproductive (second level) is the presence of the student's motivation towards self-realization through creativity, self-awareness, self-correction and self-development of some creativity.

Aspirational (third level) is characterized by steady pursuit of mastering theoretical and methodological foundations of creative activity, deep comprehension of the system based on their own experience, sustainable desire to use the results of reflection in the personal and professional self-improvement. At this level, there is a transition from a theoretical understanding of the phenomenon of creativity to the level of the personal importance for the student.

Creative level (fourth level - the highest) includes students' acquirement of holistic expertise, tendency for their integrated use in dealing with complex situations and in creative organization of educational process; acquirement of superior knowledge about the features of creative activity; navigating freely within modern pedagogical concepts of personal creative development and using this knowledge in educational process modeling.

The activity of the student becomes flexible exploratory in nature in terms of transfer of knowledge and methods at the level of the transformation of previously learned work programs for solving creative problems and finding solutions. This results in a significantly new information, the discovery of new aspects of the phenomenon, events, the express of their own opinions, estimates based on a comprehensive analysis of the initial data of the problem to be solved; formulation of new problems, hypotheses and development of a plan solution.

To diagnose the level of development of students' creative abilities, we used the technique of creative abilities' diagnosing by Torrance (1964), that was adapted by Voronin (1999), a methodology for evaluation of the analytical orientation, developed by Sukhobskaya and Gorbunova (1990) and using the questionnaire "My reflexive difficulties".

The study was initiated with determination of the students' creative abilities development. This involved using pop quiz, consisting of test, the results of which helped to evaluate benchmark data of the students' creative abilities development. All data on the quantitative and qualitative measurements we have summarized and divided into levels of creative abilities' development. $20 \%$ of the students are on spontaneous experiental level, $45 \%$ are on reproductive, $25 \%$ are on aspirational level and $10 \%$ of the students are on creative level.

In addition, more than half of the students' self-assessment of analytical skills doesn't tend to be high. Thus, $64 \%$ 
of them rated their ability to analyze the causes of the difficulties in teaching situations in 1.6 points. The median capacity for introspection was only $29.6 \%$.

Overall, the results of ascertaining experiment showed that there are some imperfections of psycho-pedagogical nature:

- Low rate of students' participation in the seminars and workshops;

- Dissatisfaction with their own progress, emotional nature of the lesson;

- Lack of students' creativity in the educational process;

- The need for increased teacher-student interaction in the process of creative activity;

- The need for reflexive assessment of lessons.

The second stage was designed for formative experiment in its final form, which revealed the efficiency degree of the developed pedagogical conditions. At this stage, we have made a special emphasis on the development and implementation of tasks and exercises in accordance with the logic of development of students' creative abilities.

It includes the need to use the entire arsenal of scientific methods of academic knowledge, in terms of training courses ("Methodology and methods of pedagogical research", "Family Pedagogy", "Social pedagogy" etc.), which eventually allow to reach the objectives of education and to solve creative tasks.

The purpose of the process is the creation of necessary conditions for the development of creative abilities as a holistic phenomenon, i.e. expressed in a creative activity and independence, adequate orientation in problem pedagogical situation on the basis of a positive self-actualization and self-development of analytical skills, research skills and knowledge.

\section{Results}

\subsection{The Results of the Control Experiment}

The tasks of the final control experiment were the following:

- Measurement of dynamics of students' creative abilities

- An overall assessment of the effectiveness of the results obtained in the experiment and obtaining generalization.

With the aim to characterize particularly the changes occurred in the students' creative abilities development, we propose the table where levels are shown in percentage terms.

Table.1 Dynamics of the creativity levels in $\%$

\begin{tabular}{lllllllll}
\hline $\begin{array}{l}\text { Number of } \\
\text { students }\end{array}$ & $\mathbf{1}$ & $\mathbf{1}$ & $\mathbf{2}$ & $\mathbf{2}$ & $\mathbf{3}$ & $\mathbf{3}$ & $\mathbf{4}$ & $\mathbf{4}$ \\
$\mathbf{6 2}$ people & before & after & before & After & before & after & before & after \\
\hline 100 & 20 & 11 & 45 & 34 & 25 & 37 & 10 & 18 \\
\hline
\end{tabular}

1- spontaneous experiental, 2- reproductive, 3- aspirational, 4- creative

The results of control sample and the table shows that, there was a shift in the development of creative abilities of students. Analysis of the final study of the students' creative abilities development leads to the conclusion that there is a tendency to a marked increase in the level of performance.

In addition, there have been changes in the analysis of their analytical skills, as confirmed by expert judgment as well. Thus, $83 \%$ of them rated their ability to analyze the causes of the difficulties in pedagogical situation in 2.3 points. The median capacity for introspection was $53.8 \%$.

The results were verified by methods of mathematical statistics to determine the availability of reliable links between the various sets of statistics. We used Spearman's rank correlation and Pearson's correlation coefficient. As a result, the following was proved:

1) There is a highly significant correlation between the level of students' creative abilities development before and after the formative experiment $(\mathrm{rs}=0.957)$

2) There is a highly significant correlation between aspiration level received before and after the experiment (rs 
$=0.592)$

3) There is also apparent high significant connection between indicators ( $\mathrm{rs}=0.956)$

4) There is a significant correlation between self-esteem ( $r s=0.374 ; p=0.05$ ).

5) There is a significant correlation between assessments before and after the experiment ( $r s=0.443 ; p=0.05)$.

\section{Discussions}

Development of creative abilities as an object of pedagogical science had its own background and was revealed in the works of many teachers, psychologists and philosophers. Analysis of pedagogical heritage showed that many of the ideas of the past haven't lost their relevance today.

At the same time, we should take into account the fact that the study of creative abilities of students is a complex and quite controversial problem and is still open to discussion in psychological and pedagogical literature.

Despite different interpretations in the scientific literature, many scholars point out that the development of creative skills implies the development of the ability to solve creative problems and to connect non-correlating notions, and the use of students' subjective experience. This forms the basis for the consistent and dialectical thinking, arbitrary, productive and spatial imagination, the use of heuristic and algorithmic methods of organizing students' creative activity.

It is important to note that the development of creativity and creative abilities is viewed as a decisive step to overcome passive and contemplative nature of teaching.

\section{Conclusion}

The theoretical analysis of the problem of university students' creative abilities development allowed to identify basic theoretical positions. These are the principles that should form the basis for organizing the process of creative abilities development: consistence, continuity and problem-based principles; training and research activity; motivation of creative activity; the principle of individualization and differentiation of learning activities.

The general characteristic features of pedagogical experience are:

- The inclusion of students in the creative and search activity;

- Teacher-students co-creativity;

- The use of new educational technologies, intensifying the learning process that imply the immersion of the future experts and their self-analysis;

- Individualization and differentiation of teaching.

The pedagogical experiment proved the relevance of the hypothesis and theoretical basis chosen for the implementation of the proposed pedagogical conditions of university students' creative abilities development.

Given the complexity and multidimensionality of the problem of university students' creative abilities development, the study does not claim its complete and comprehensive explication. The research and testing of its results provide a basis for further search aimed at optimizing the development of creative abilities of university students.

\section{Acknowledgments}

The work is performed according to the Russian Government Program of Competitive Growth of Kazan Federal University

\section{References}

Biktagirova, G. F., \& Valeeva, R. A. (2014). Development of the teachers' pedagogical reflection. Life Science Journal, 11(9s), 60-63.

Biktagirova, G. F., \& Valeeva, R. A. (2013). Technological approach to the reflection development of future engineers. In 2013. International Conference on Interactive Collaborative Learning (p. 427). ICL. http://dx.doi.org/10.1109/ICL.2013.6644615

Bogoyavlenskaya, D. B. (2002). Psychology of creativity. Moscow: Academiya.

Bono, E. (1993). Serious Creativity: Using the Power of Lateral Thinking to Create New Ideas. N.Y.

Ganieva, Y. N., Sayfutdinova, G. B., Yunusova, A. B., Sadovaya, V. V., Schepkina, N. K., Scheka, N. Y., ... Salakhova, V. B. (2015). Structure and content of higher professional school lecturer education competence. 
Review of European Studies, 7(4), 32. http://dx.doi.org/10.5539/res.v7n4p32

Ganieva, Y. N., Azitova, G. S., Chernova, Y. A., Yakovleva, I. G., Shaidullina, A. R., \& Sadovaya, V. V. (2014). Model of high school students' professional education. Life Science Journal, 11(8), 504.

Greenberg, D. (1974). Outline a New Philosophy. Sudbury Valley School Press.

Guilford, J. P. (1950). Creativity. American Psychologist, 5. http://dx.doi.org/10.1037/h0063487

Guilford, J. P. (1967). The Nature of Human Intelligence. N.Y.

Ivanenko, N. A., Akhmetov, L. G., Lavrentiev, S. Y., Kartashova, E. P., Lezhnina, L. V., Tzaregorodtzeva, K. A., \& Khairullina E. R. (2015). Features of Modeling the Formation of Teaching Staff Competitiveness. Review of European Studies, 7(3), 37-42. http://dx.doi.org/10.5539/res.v7n3p37

Ivanov, V. G., Shaidullina A. R., Drovnikov A. S., Yakovlev S. A., \& Masalimova A. R. (2015). Regional Experience of Students' Innovative and Entrepreneurial Competence Forming. Asian Social Science, 11(1), $35-40$.

Khairullina, E. R., Valeyev A. S., Valeyeva G. K., Valeyeva N. S., Leifa A. V., Burdukovskaya E. A., \& Shaidullina A. R. (2015). Features of the Programs Applied Bachelor Degree in Secondary and Higher Vocational Education. Asian Social Science, 11(3), 213-217.

Khusainova, G. R. (2010). Development of creative abilities of students-The future managers in the process of foreign language training ( $\mathrm{PhD}$ dissertation). Kazan: KNRTU.

Khutorskoy, A. V. (2000). Development of creative abilities. Moscow: Eidos.

Kovaleva, N. I., Valeyeva, N. Sh., Avilova, N. L., Kharisova, G. M., Khayrutdinov, R. R., Khairullina, E. R., \& Shaikhlislamov, A. K. (2015). Recommended Practices for Improving the Competitiveness of the Russian Education Services Market under the Conditions of the International Educational Integration. Review of European Studies, 7(4), 1-5. http://dx.doi.org/10.5539/res.v7n4p1

Lisitzina, T. B., Pavlova, A. V., Khanmurzina, R. R., Vlasova, V. N., Chitalin, N. A., Maksimov, I. N., \& Zakirova, V. G. (2014). Features of the Professional and Motivating Training Content Design for Students Majoring in "Tourism". Asian Social Science, 11(1), 148. http://dx.doi.org/10.5539/ass.v11n1p148

Lopatina, O. V., Fassakhova, G. R., Akhmetova, L. A., Gatin, R. G., Yarullina, A. S., Nikishina, S. R., \& Khairullina, E. R. (2015). The Technology of Forming the Students' Research Competence in the Process of Learning a Foreign Language. Asian Social Science, 11(3), 152-157.

Masalimova, A. R., \& Sabirova, L. L. (2014). Multi-dimensional classification of types and forms of corporate education. American Journal of Applied Sciences, 11, 1054-1058. http://dx.doi.org/10.3844/ajassp.2014.1054.1058

Masalimova, A. R., \& Sabirova L. L. (2015). Mentors and Trainees Professional Interaction Features at the Modern Enterprises in Russia. Review of European Studies, 7(4), 20-26. http://dx.doi.org/10.5539/res.v7n4p20

Matyushkin, A. I. (2003). Thinking, learning and creativity. Moscow: MODEK.

Sakhieva, R. G., Ibatullin, R. R., Biktemirova, M. K., Valeyeva, G. K., Pchelina, O. V., Valeyeva, N. Sh., Minsabirova, V. N., \& Khairullina, E. R. (2015). The Essential, Objective and Functional Characteristics of the Students' Academic Mobility in Higher Education. Review of European Studies, 7(3), 335-340. http://dx.doi.org/10.5539/res.v7n3p335

Shadrikov, V. D. (2004). Development of abilities. Elementary School, 4.

Shaidullina, A. R., Merzon, E. E., Zakirova, V. G., Mokeyeva, E. V., Karev, B. A., Burdukovskaya, E. A., \& Polevaya, N. M. (2015). The Peculiarities of Perspective Students Selection Mechanism by the Future Employers-Enterprise. Review of European Studies, 7(1), 68-73.

Shaidullina, A. R., Fassakhova, G. R., Valeyeva, G. K., Khasanova, G. B., Komelina, V. A., \& Ivanova, T. L. (2015). A Comparative Research on Levels of Students' Formation Skills of Their Career Advancement Portfolio in Secondary and Higher Education Systems. Asian Social Science, 11(1), 375-379.

Shmakova, L. E. (2009). Integrated development of creative abilities of design students in teachers' training university ( $\mathrm{PhD}$ dissertation). Ekaterinburg.

Shulga, E. P. (2010). Structure and development of creative abilities of younger students (PhD dissertation). 
Moscow.

Sibgatova, K. I., Sabirov, I. T., Sadovaya, V. V., Vlasova, V. K., Leyfa, I., Yatsevich, L. P., \& Fassakhova, G. R. (2015). Pedagogical potential of the career guidance course "Professional career planning" to form pupils and students' self-determination in the integrated system "school-vocational college". Review of European Studies, 7(1), 80 .

Sibgatova, K. I., Mirzagalyamova, Z. N., Pupysheva, E. L., Mirzanagimova, F. I., Shkinderova, I. N., Nuriyeva, E. N., ... Schepkina, N. K. (2015). The Educational Institution Teachers and Professional Community Representatives' Readiness Formation for the Joint Pupils' Career Guidance Implementation. Review of European Studies, 7(1), 74-79.

Sukhobskaya, G. S., \& Gorbunova, L. L. (1990). Development of research orientation of the teacher in the process of training. Leningrad: Institute of General Adult Education APN.

Telegina, N. V., Galimova, E. G., \& Masalimova, A. R. (2015). The Structure and Content of the Model of Pedagogical Conditions Binary Approach to Optimization of Control and Diagnostic Functions in Teaching "General pedagogy" to Students. Asian Social Science, 11(1), 364-368.

Torkunova, J. V., Khairullina E. R., Komelina V. A., Volkova N. V., \& Ponomarev K. N. (2014). The Peculiarities of Qualitative Information, Analytical Maintenance Innovative and Educational Activity Technological Projection in Higher Educational Institution. Life Science Journal, 11(8s), 498-503. Retrieved from http://www.lifesciencesite.com

Torrance, E .P. (1964). Guiding creative talent, Englewood Cliffs. NY: Prentice-Hall.

Tunik, E. E. (1998). Diagnosis of creativity E. Torrance's test. St. Petersburg: IMATON.

Valeeva, R. A. (2010). Philosophical and psycho-pedagogical bases of the competitive person formation in the modern university. In Modern problems of higher education: Achievements and prospects (pp. 325-330). Almaaty: Kazakh University.

Valeeva, L. A., \& Valeeva, R. A. (2013). Development of future engineers' critical thinking in foreign language teaching. In 2013 International Conference on Interactive Collaborative Learning (p. 438). ICL. http://dx.doi.org/10.1109/ICL.2013.6644619

Voronin, A. N. (1999). Intellect and creation. Moscow: Institute of Psychology of the Academy of Sciences

Vygotsky, L. S. (1991). Imagination and creativity in childhood: Psychological essay. Moscow: Prosvescheniye.

Wollach, M. A., \& Kogan, N. A. (1965). A new look at the creativity-Intelligence distinction. Journal of Personality, 33. http://dx.doi.org/10.1111/j.1467-6494.1965.tb01391.x

\section{Copyrights}

Copyright for this article is retained by the author(s), with first publication rights granted to the journal. This is an open-access article distributed under the terms and conditions of the Creative Commons Attribution license (http://creativecommons.org/licenses/by/3.0/). 